\title{
Basement Car Parks: A Domicile of Radon Pollution Validated By Discomfort Index
}

\author{
$\mathrm{AH}$ Bu-Olayan and BV Thomas
}

\begin{abstract}
Investigation in the public basement car parks from six Governorates of Kuwait showed the influence of radon concentrations and the probable discomfort caused while parking their cars. Radon concentrations in the public semi-closed car parks distributed in the six Governorate sites were analyzed using Rad7 (Durridge, USA).The peak concentration of radon from the six Kuwait Governorate car parks was relatively higher during the winter season $\left(63.15 \mathrm{~Bq} / \mathrm{m}^{3}\right)$ than during the summer season $\left(41.73 \mathrm{~Bq} / \mathrm{m}^{3}\right)$.This validated the influence of relative humidity and temperature, the components of discomfort index (DI). The mean annual absorbed dose rate radon $\left(D_{R n}\right)$ and annual effective dose $\left(H_{E}\right)$ was observed high when the assessment included the car parks and the surrounding residential apartment and office premises. The $D_{R n}(0.02 \mathrm{mSv} / \mathrm{y})$ and $\left.\mathrm{H}_{E} 0.06 \mathrm{mSv} / \mathrm{y}\right)$ of radon in the car parks alone indicated radon concentrations below the permissible limits. Statistical assessment indicated the significant differences between the dependence of indoor radon concentrations on the timeseries, temporal and spatial distribution in the six Kuwait Governorate car parks. Hence, the need to ameliorate the radon concentrations in the indoor environment becomes indispensable in the near future.
\end{abstract}

Keywords- Car parks, Radon, Thermal-Humidity Stress, Pollution

\section{Introduction}

Radon in the indoor air is found to cause $16 \%$ more risk of lung cancer in humans from 100 Becquerel per cubic meter $\left(\mathrm{Bq} / \mathrm{m}^{3}\right)$ onwards [1]. Radon enters the basement floors through cracks in walls and other openings from rock and soil and observed everywhere [2,3,4]. Unlike their concentrations found outdoor, radon gets trapped in the indoor environment and may accumulate over time that causes respiratory illness to humans $[5,6]$. Sealing cracks and openings and appropriate ventilation system can significantly reduce the radon levels [3]. Estimation reveals $50 \%$ of radon in humans from the radioactive decay of ${ }^{238} \mathrm{U}$ is from the environment [7]. Radon levels are higher in confined places and aged buildings in contact with the soil [8]. Radon reaches high concentrations in premises that are dependent upon the location, ventilation rate, temperature and relative humidity $[9,10]$. Radon concentrations in the building vary with time both, diurnally and seasonally as a result of the effect of meteorological changes, soil gas and ventilation in buildings $[11,12]$.

AH Bu-Olayan \& BV Thomas

Kuwait University

Kuwait
Studies in the Arab countries showed low radon concentrations $\left(29-58 \mathrm{~Bq} / \mathrm{m}^{3}\right)$ in most residential areas above the ground level when compared to the radon levels in the basements $\left(150-242 \mathrm{~Bq} / \mathrm{m}^{3}\right)$ and some areas that were involved in industrial activities $[13,14,15]$. Yet another study [16] revealed the cause of high indoor radon accumulation due to poor radon exhalation and improper building design. Such results indicated the need for preventive measures to radon concentrations.

In Kuwait, the rocks contain neither traces of volcanic activities nor with minerals constituents. Therefore, the radon dispersion from the soil is very low. Seasonal influence showed high radon concentrations during the winter than during the summer season [17]. Studies $[15,18,19,20]$ showed high radon concentrations in the basement of buildings $\left(58 \mathrm{~Bq} / \mathrm{m}^{3}\right)$ than the first and second floors $\left(29 \mathrm{~Bq} / \mathrm{m}^{3}\right.$ and $15 \mathrm{~Bq} / \mathrm{m}^{3}$ ) respectively. However, Maged [21] observed the reverse phenomenon of radon concentrations variation in the first floor $\left(16 \mathrm{~Bq} / \mathrm{m}^{3}\right)$ and the second floor $\left(23.8 \mathrm{~Bq} / \mathrm{m}^{3}\right)$ of schools in Kuwait respectively, attributing to the lack of proper heating, ventilation, air-conditioning (HVAC) system and poor maintenance of the building at the second floor. Findings [22,23,24] confirmed the maintenance of a standard thermal comfort index for buildings occupants. People living in large cities are subjected to greater risk to mortality due to high air temperature when compared to the surrounding country and calculated by Thom's formula [25], a computation of Discomfort Index (DI). Wind action, chemical pollutants and social load plays a role in the comfort of indoor occupants [26]. Investigations on radon and DI were made in these areas. The recent rise in Kuwait population witnessed the increase of automobiles [27]. Observations witnessed deterioration of basic amenities and poor Kuwait car parks maintenance. No studies revealed the spatial and temporal variations in relation to the basic amenities of the car parks in Kuwait. The present study determined the (a) time series $(24 \mathrm{~h})$ effect of radon concentrations in the public basement car parks encompassing the six Kuwait Governorates (b) varying radon concentrations during the winter and the summer seasons and, (c) combined effects between the radon concentrations and the discomfort index (DI) components namely, temperature and humidity of the sampled locations.

\section{Materials and Methods}

The combined effects of radon and environmental variables was conducted at random in the public basement car parks distributed in the six Governorate areas (GI-GVI: Fig.1). Kuwait experiences a hot and dry climate with occasional and unpredictable mild to moderate dust storms.

A kestrel-4500 weather monitor recorded the ambient air temperature $\left({ }^{\circ} \mathrm{C}\right)$ and relative humidity (\%) from six 
public basement semi-closed car parks distributed in the six Kuwait Governorate areas (Fig. 1). Simultaneously, a Durridge $\operatorname{Rad} 7$ meter detected and measured the radon concentrations $\left(\mathrm{Bq} / \mathrm{m}^{3}\right)$ in the car parks. These measurements were recorded every hour for $24 \mathrm{~h}$ at an approximate height of $1.5 \mathrm{~m} \pm 0.3 \mathrm{~m}$ every month during the years 2013-2015 and classified by summer and winter sample variations. This height was based on the possible human breathing exposure to radon concentrations after parking their car. Cars parked by non-smoking respondents for at least three times a day and who spent their time in the basement for more than $10 \mathrm{~min}( \pm 2 \mathrm{~min})$ were alone considered for the present study. The mean monthly data were recorded by calculating the discomfort index [25]

The mean seasonal radon concentrations from the six public basement car parks were plotted along with the discomfort index (DI) and validated for the State of Kuwait. The standard DI [25] value (Table 1) was compared with that of the DI concentrations to determine the percentage of the residents who might have experienced discomfort while parking their cars in the car parks at different intervals of time. The DI value was correspondingly interrelated with the different concentrations of radon for a given time to determine the temporal and spatial effect of radon concentrations from the sampled area.

NIST standard reference material (SRM 4968) yielded the Quality Assurance of the radon concentrations. The certified volume of radon-222 concentrations was allowed to accumulate radon in a container at high atmospheric humidity using an Alpha-pump. This container was connected to the RAD7 and radon concentrations released by the standard material was measured. Samples with $95 \% \pm 2.0$ recovery to that of the SRM alone was used to validate the quality measure of the present results. In addition to the above study, the annual absorbed dose of radon $\left(D_{R n}\right)$ and the effective dose rate of radon $\left(\mathrm{H}_{\mathrm{E}}\right)$ from each car park was calculated. The radiation weighting factor $(\mathrm{WR}=20)$ and tissue weighting factor (WT $=0.12$ ) followed ICRP method [29]. The total annual dose of radon in an individual was derived by calculating the total effective dose rate of radon $\left(\Sigma \mathrm{H}_{\mathrm{E}}\right)$.

\section{Results}

Kuwait houses innumerable semi-closed car parks of varying capacity in the six Governorates. A 24h monitoring in the car park using Rad7 revealed the peak radon concentrations at $8: 00 \mathrm{AM}\left(62.39 \mathrm{~Bq} / \mathrm{m}^{3}\right)$ and at 8:00PM $\left(62.12 \mathrm{~Bq} / \mathrm{m}^{3}\right)$ during the peak winter seasons of December-January. Time-wise radon concentrations was high at $8: 00 \mathrm{AM}\left(42.93 \mathrm{~Bq} / \mathrm{m}^{3}\right)$ and $8: 00 \mathrm{PM}(39.65$ $\mathrm{Bq} / \mathrm{m}^{3}$ ) in the summer season (Fig.3). Radon concentrations was moderately high during the months of November and February (early and late winter) and comparatively low in October and March (onset and late winter) (Fig.2). However, radon concentrations was found lower during the summer seasons than during the winter seasons.
The relative humidity $(\mathrm{RH})$ was found high in the ranges $60.75 \%-86.5 \%$ during the winter season when compared to RH (27.25\%-55.42\%) during the summer season. RH was observed high between 7:00PM and 9:00AM and low between 11:00AM and 2:00PM. Season-wise analysis revealed significant differences of $\mathrm{RH}$ between the summer and the winter seasons. Time-series (24h) and season-wise (summer and winter) ANOVA tests revealed significant results between the radon concentrations and relative humidity (Table 2: A, C).

The mean temperature in the car parks ranged between $17^{\circ} \mathrm{C}-26^{\circ} \mathrm{C}$ and $33.4^{\circ} \mathrm{C} 42.96^{\circ} \mathrm{C}$ during the winter and the summer seasons, respectively. The radon concentrations in the basement car parks was found to increase with decreasing temperature irrespective of both the seasons. The present study observed such influence of high radon concentrations in the basement car parks during the winter season as well, during the early morning and late evening when compared to their concentrations during the summer and during the day time until dusk. Timewise ANOVA test (analysis of variance) showed no significance between the radon concentrations and temperature especially during the day time due to temperature variations (Table 2: B, D). However, ANOVA indicated significance between the seasons and radon concentrations with time and temperature variation (Table 2: B, D).

In the present study, season-wise analysis revealed high discomfort index (DI) at high relative humidity (RH) and low temperature in the basement car parks. However, DI was not found correlated with radon concentration when temperature varied during the day time. Discomfort index (DI) was also found in region with more traffic and congested population.

Site-wise analysis revealed high radon concentrations in sites GVI followed by GIV and GII car parks when compared to the radon concentrations in the car parks from the other Governorate areas (Figs. 4a-4d).

Statistical tests by ANOVA revealed significant difference between site-wise radon concentrations and discomfort index (DI) including their componentsrelative humidity and temperature during both the summer and the winter seasons (Table $2 \mathrm{E}$ ).

The annual absorbed dose of radon $\left(D_{R n}\right)$ in the car parks was found high in GVI followed by GIV $>$ GII $>$ GI $>$ GIII $>$ GV (Table 3 ). The overall mean $D_{R n}$ in the car park $(0.02 \mathrm{mSv} / \mathrm{y})$ was comparatively lower than the $D_{R n}$ in residential apartment $(0.37 \mathrm{mSv} / \mathrm{y})$ and offices $(0.09 \mathrm{mSv} / \mathrm{y})$ surrounding the car park areas (Table 3). The mean annual effective dose $\left(\mathrm{H}_{\mathrm{E}}\right)$ of radon for an individual surveyed near the car park was $0.06 \mathrm{mSv} / \mathrm{y}$ whereas, the $\mathrm{H}_{\mathrm{E}}$ of radon in the residential apartment and office and within $0.2 \mathrm{Km}$ radius distance away from the car park were found to be $0.22 \mathrm{mSv} / \mathrm{y}$ and $0.88 \mathrm{mSv} / \mathrm{y}$ respectively. The collective dose of radon concentration $\left(\Sigma \mathrm{H}_{\mathrm{E}}\right)$ from car parks, offices and residential apartment of the six Kuwait Governorates (GI-GVI) ranged between $1.01 \mathrm{mSv} / \mathrm{y}$ and $1.28 \mathrm{mSv} / \mathrm{y}$ (Table 3). 


\section{Discussion}

More than 1.5 million vehicles were cars registered by the residents of Kuwait for domestic and public utilities [27]. The spacing capacity of each car park ranged between 2500 and 3000 cars with few exception that range between 4000 and 12000 cars in certain private shopping malls. The present study during the years 20132015 , revealed a direct proportion of pollution from cars with that of the corresponding car parks, automobiles on the road and the recent rise of population in Kuwait. Studies [13,17,21] reported the effects of radon concentrations in indoor and outdoor environment of Kuwait. Limitation to such studies attributed to the: (a) difficult technicalities involved in their assessment, (b) inaccessibility of sampling strategies in the public and, (c) unawareness to respiratory illness caused by radon and their progeny. In the wake of respiratory illness to residents and in line with the earlier investigations $[1,5,10,15,19,20]$, this study determined the radon concentrations in the car parks from the six Kuwait Governorates, the frequency and number of cars parked in the semi-closed basement besides, the discomforts endured by the residents of Kuwait.

The high radon concentrations in the car parks attribute to the entry of radon through cracks or crevices in the basement from the surrounding soil and in relation to low temperature and high relative humidity from the outdoor environment thus, suggesting the temperature inversion that tend to trap the radon closer to the ground $[7,12,14,16]$.

Relative humidity (RH) was found correspondingly high with increasing radon concentrations irrespective of the two seasons attributing RH as the one of the dependent factor for the increase of radon concentrations. This study observed an increasing trend of radon concentrations with RH. This was in line with the earlier findings $[9,18,23,26]$.

Earlier $[4,7,9,11]$ researchers hypothesized the influence of radon concentrations from the outdoor environment. A diminutive vertical mixing of air especially in the early morning and late evening during winter caused the low diffusion rate of radon into the atmosphere and created high radon concentrations near the ground. High temperature in arid region influenced the radon concentration due to the increased vertical mixing of air from the outdoor environment. This enabled the radon concentrations dissipate from the basement car parks to the outdoor environment through possible ventilation and thus, lowering the radon concentrations in the basement during the summer season.

The high Discomfort index (DI) at low temperature and high RH increasing the radon concentrations attributed to the permeability of the soil that mobilizes radon into the spaces in the basement buildings. This was found in agreement with the observations of the previous investigators $[2,3,6,9,22]$ and observed within the standard permissible limits $[8,24,25,26]$.

The high radon concentrations in car parks from sites GVI and GIV attributed to the influence of (a) external sources from the soil, (b) poor car parks maintenance in these areas and, (c) exhaust smoke emanated from the cars due to frequent car parking by the residents in such populated areas.

Furthermore, the high annual effective dose $\left(\mathrm{H}_{\mathrm{E}}\right)$ of radon attributed to the long exposure period (10h 14h) of an individual in their residential apartment when compared to the car parking areas. The collective dose of radon concentration $\left(\Sigma \mathrm{H}_{\mathrm{E}}\right)$ was found within the action level of $3-10 \mathrm{mSv} / \mathrm{y}$ recommended by ICRP [29] but higher than the global average of $1.15 \mathrm{mSv} / \mathrm{y}$ as recommended by UNSCEAR [7] especially, with the $\mathrm{H}_{\mathrm{E}}$ of samples collected from car parks of GVI, GIV and GII. Thus, the present findings indicated the necessity of preventive measures to radon concentrations especially in car parks.

\section{Conclusion}

The present study assessed the time-series, season-wise and site-wise indoor radon concentrations in car parks from six Kuwait Governorate areas. The radon concentrations were measured from June 2013 to May 2015. Observation showed the radon concentrations in the ranges $24.62 \mathrm{~Bq} \cdot \mathrm{m}^{3}-63.15 \mathrm{~Bq} \cdot \mathrm{m}^{3}$. The mean radon concentrations during the winter season was found higher than the global average radon concentrations [7] of 40 $\mathrm{Bq} / \mathrm{m}^{3}$. The mean annual absorbed dose rate $\left(\mathrm{D}_{\mathrm{Rn}}\right)$ and the mean annual effective dose rate $\left(\mathrm{H}_{\mathrm{E}}\right)$ assessed from the car parks was lower than te standard limits [7]. However, the annual effective dose rate $\left(\mathrm{H}_{\mathrm{E}}\right)$ from indoor residences and offices surrounding the car parks were found higher than the standards limits [28] indicating the need for the radon amelioration process in the near future.

\section{Acknowledgment}

This study was financially sponsored by the Kuwait Foundation for Advancement of Sciences (KFAS: grant No. KFAS-2013-1401-02). We also thank the Vice Dean, Research and Lab Affairs and the Research Administration, Kuwait University for their timely support.

\section{References}

1. Axelsson G, Andersson EM, Barregard L. Lung cancer from radon exposure in dwellings in Sweden: how many cases can be prevented if radon levels are lowered? Cancer Causes Cont 2015; 26 (4): 541547. DI10.1777/s10552-015-0531-6

2. Carvalho FP, Oliveira JM, Arezes BEP, Baptista JS, Barroso MP, Carneiro P, Cordeiro P, Costa N, Melo R, Miguel AS, Perestrelo G. Radon exposure (ionizing radiation) in underground work places. Internat Symp Occupat Safe Hyg 2015; 3: 61-63.

3. Arif M, Tufail M, Iqbal MA. Measurement of radon concentration and exhalation rate in some mud houses of district Lahore, Pakistan. Indoor Built $\begin{array}{llll}\text { Environ 2014; } 23 & \text { (6): 774-784. }\end{array}$ DI10.1177/1420326X134812345. 
4. Miro C, Andrade E, Reis M, Madruga MJ. Development of a couple of methods for measuring radon exhalation from building materials commonly used in the Iberian Peninsula. Radiat Prot Dosim 2014; 160 (1-3): 177-180. DI10/1093/rpd/ncu063

5. Conti S, Meli P, Menelli G, Solimini R, Toccaceli V, Vichi M. Epidemiologic study of mortality during the summer 2003 heat wave in Italy. Environ Res 2005; 98, 390-399.

6. Nastos PT, Matzarakis A. Weather impacts on respiratory infections in Athens, Greece. Internat $\mathbf{J}$ Biometeorol 2006; 50: 358-369.

7. UNSCEAR. Report, Sources-to-Effects Assessment for radon in homes and workplaces. Volume II, Annex E. United Nations scientific committee on the effect of atomic radiation (UNSCEAR). United Nation, New York, USA; 2006.

8. Muulerova M, Kozak K, Kovacs T, Csordas A, Grzadziel D, Holy K, Mazur J, Moravcsik A, Neznal M, Neznal N, Smetanova I. Preliminary results of indoor radon survey in V4 countries. Radiat Prot Dosim 2014; 160 (1-3): 210-213. DI.10.1093/rpd/ncu081.

9. Gregoric A, Vaupotic J, Sebela S. The role of cave ventilation in governing cave air temperature and radon levels (Postojna Cave, Slovenia). Internat J Climat 2014; $34 \quad$ (5): $\quad$ 1488-1500. DI10.1002/joc.3778.

10. Akbari K, Mahmoudi J, Ghanbari M. Influence of indoor air conditions on radon concentration in a detached house. J Environ Radioact 2013; 116: 6673. DI10.1016/j.jenvrad.2012.08.013.

11. Kobayashi T. Temporal variation of radon progeny ratio in outdoor air. Health Phys 2002; 83: 287-292.

12. IAEA. Radiation protection against radon in work places other than mines. Safety Report Series 2003; 33, IAEA, Vienna, Austria.

13. Al-Azmi Al-Abed T, Alnasari MS, Borham EE, Chekir Z, Khalifa MS, Shweikani R. Coordinated indoor radon surveys in some Arab countries. $\begin{array}{llll}\text { Radioprotect } 2012 ; & 47 \quad \text { (2): } 205-217 .\end{array}$ DI10.1051/radiopro/2011160.

14. Kapdan E, Altinsoy N. Indoor radon levels in workplaces of Adapazari, North-Western Turkey. J Earth Syst Sc 2014; 123 (1): 213-217.

15. Alkan $\mathrm{T}$, Karadeniz O. Indoor ${ }^{222} \mathrm{Rn}$ levels and effective dose estimation of academic staff in IzmirTurkey. Biomed Environ Sci 2014; 27 (4): 259-267.

16. Orlando P, Trenta R, Bruno M, Orlando C, Ratti A, Ferrari S, Piardi S. A study about remedial measures to reduce ${ }^{222} \mathrm{Rn}$ concentration in an experimental building. J Environ Radioact (2004) 65: 203-213. PMID: 15050359

17. Adel AM, Vasisht CM, Sabol J. Measurement of indoor radon concentrations in Kuwait. Environ Internat (1987) 13 (4-5): 323-330. DI10.1016/01604120(87)90187-5.

18. El-May MV, Chahed N, Mtimet S. Radon concentrations in some dwellings of Tunisia. Health Phys 2004; 86 (2): 150-154.
19. Dixon DW. Radon exposures from the use of natural gas in buildings. Radiat Prot Dosim 2001; 97: 259264.

20. Abel Ghany HA. Exposure of school children to alpha particles. Iranian J Radiat Res 2008; 6 (3): 113-120.

21. Maged AF. Radon concentrations in elementary schools in Kuwait. Health Phys 2006; 90 (3): 258262.

22. Abrittie G, Muzi G. Indoor air quality in offices and other non-industrial working environments. La Medicina del lavoro 2006; 97 (2): 410-417.

23. ASHRAE. American Society of Heating, Refrigeration, and Air-Conditioning Engineers Standard. Thermal Environmental Conditions for Human Occupancy 2010; 55.

24. Yousif TA, Tahir HMM. Application of Thom's thermal discomfort index in Khartoum State Sudan. J Forest Prod Indust 2013; 2 (5): 36-38. ISSN: $2325-$ 4513.

25. Thom EC. The discomfort index. Weather Wise 1959; 12 (2): 57-60.

26. Schnell I, Potchter O, Yaakov Y, Epstein Y, Brener $\mathrm{S}$, Hermesh $\mathrm{H}$. Urban daily life routines and human exposure to environmental discomfort. Environ Monit Assess 2012; 184: 4575-4590. DI10.1007/s10661-011-2286-1

27. Kuwait Times. Road accidents killed 225 people in six months - Youngsters dead in horrificcrashes.http://news.kuwaittimes.net/roadaccidents-killed-225-people-six- months-youngstersdead-horrific-crashes/\#, Kuwait Times Arab Daily Newspaper. 2014; accessed 15/11/2014.

28. ICRP. The 2007 recommendations of the International Commission on Radiological Protection ICRP publication 103, Elsevier Publishers, http://www.icrp.org /docs/ ICRP Publication 103-Annals of the ICRP $37 \% \quad 282$ 4\%29- Free_extract. pdf. 2007; 35 accessed 04/04/2015.

Table 1. Discomfort index

\begin{tabular}{ll}
\hline$*$ DI ( C) & Discomfort Conditions \\
$<21$ & No Discomfort \\
$21-24$ & Under 50\% population feels discomfort \\
$24-27$ & Most 50\% population feels discomfort \\
$27-29$ & Most of population suffers discomfort \\
$29-32$ & Everyone feels severe stress \\
$>32$ & State of medical emergency \\
\hline DI: Discomfort index *Thom. Weather Wise 195912(2):57-60.
\end{tabular}


Proc. of The Fifth Intl. Conf. On Advances in Applied Science and Environmental Engineering - ASEE 2016 Copyright (C Institute of Research Engineers and Doctors, USA .All rights reserved.

ISBN: 978-1-63248-086-6 doi: 10.15224/ 978-1-63248-086-6-02

Table 2. ANOVA of radon concentrations and environmental factors in car parks

\begin{tabular}{|c|c|c|c|c|c|c|}
\hline Source of Variation & Ss & df & $\mathrm{F}$ & P-value & F ratio & Significance \\
\hline \multicolumn{7}{|c|}{ A. Radon conc. Vs. relative humidity with time during winter/day } \\
\hline Radon Vs RH (Time) & 387.25 & 12 & 34.18 & 0.00025 & 1.91 & * \\
\hline Radon Vs RH-(Winter) & 12491.03 & 5 & 2646.59 & 0.00056 & 2.36 & * \\
\hline Error & 56.63 & 60 & & & & \\
\hline Total & 12934.92 & 77 & & & & \\
\hline Radon & \multicolumn{6}{|c|}{ Radon conc. Vs. Temperature with time during winter/day } \\
\hline \multicolumn{6}{|l|}{ (Time) } & ** \\
\hline $\begin{array}{l}\text { Radon Vs Temp.- } \\
\text { (Winter) }\end{array}$ & 14118.75 & 5 & 585.96 & 0.00052 & 2.36 & $*$ \\
\hline Error & 289.13 & 60 & & & & \\
\hline Total & 14417.34 & 77 & & & & \\
\hline \multicolumn{7}{|c|}{ Radon conc. Vs. relative humidity with time during summer/day } \\
\hline Radon Vs RH (Time) & 286.8376 & 12 & 79.14059 & 0.0004 & 1.91 & $*$ \\
\hline $\begin{array}{c}\text { Radon Vs RH- } \\
\text { (Summer) }\end{array}$ & 4975.42 & 5 & 3294.612 & 0.0008 & 2.36 & * \\
\hline Error & 18.12 & 60 & & & & \\
\hline Total & 5280.38 & 77 & & & & \\
\hline \multicolumn{7}{|c|}{ Radon conc. Vs. Temperature with time during summer/day } \\
\hline $\begin{array}{l}\text { Radon Vs Temp. } \\
\text { (Time) }\end{array}$ & 5.75 & 12 & 0.1208 & 0.99 & 1.91 & ** \\
\hline $\begin{array}{c}\text { Radon Vs Temp. } \\
\text { (Summer) }\end{array}$ & 1220.60 & 5 & 61.5916 & 0.0002 & 2.36 & $*$ \\
\hline Error & 237.81 & 60 & & & & \\
\hline Total & 1464.15 & 77 & & & & \\
\hline Site-w & \multicolumn{6}{|c|}{ Site-wise Radon conc. Vs. Environmental variables during winter and summer } \\
\hline $\begin{array}{c}\text { Radon Vs Car park } \\
\text { sites }\end{array}$ & 37.18347 & 5 & 23.61 & 0.0002 & 2.48 & * \\
\hline Variables in Winter \& & 11119.99 & 7 & 5044.23 & 0.0001 & 2.28 & * \\
\hline Summer & & & & & & \\
\hline Error & 11.02 & 35 & & & & \\
\hline Total & 11168.19 & 47 & & & & \\
\hline
\end{tabular}

Table 3 Site-wise annual doses of radon in car parks and surrounding premises

\begin{tabular}{cccc}
\hline & $\mathrm{D}_{\mathrm{Rn}}$ & $\mathrm{H}_{\mathrm{E}}$ & $\Sigma \mathrm{H}_{\mathrm{E}}$ \\
G-I:Office & 0.09 & 0.21 & \\
G-I:Residence & 0.35 & 0.84 & \\
G-I:Carpark & 0.02 & 0.06 & 1.1081 \\
G-II:Office & 0.10 & 0.24 & \\
G-II:Residence & 0.38 & 0.91 & \\
G-II:Carpark & 0.02 & 0.06 & 1.2059 \\
G-IIII:Office & 0.08 & 0.20 & \\
G-III:Residence & 0.34 & 0.82 & \\
G-III:Carpark & 0.02 & 0.06 & 1.0722 \\
G-IV:Office & 0.11 & 0.27 & \\
G-IV:Residence & 0.40 & 0.95 & \\
G-IV:Carpark & 0.02 & 0.06 & 1.2806 \\
G-V:Office & 0.08 & 0.18 & \\
G-V:Residence & 0.32 & 0.77 & \\
G-V:Carpark & 0.02 & 0.06 & 1.0106 \\
G-VI:Office & 0.09 & 0.23 & \\
G-VI:Residence & 0.41 & 0.99 & \\
G-VI:Carpark & 0.03 & 0.06 & 1.2807 \\
\hline Mean: Office & 0.09 & 0.22 & 1.33 \\
Mean: Residence & 0.37 & 0.88 & 5.88 \\
Mean: Carpark & 0.02 & 0.06 & 0.35 \\
\hline DRn: Annual absorbed dose, HE: Annual effective dose, HE: Collective
\end{tabular}

effective dose

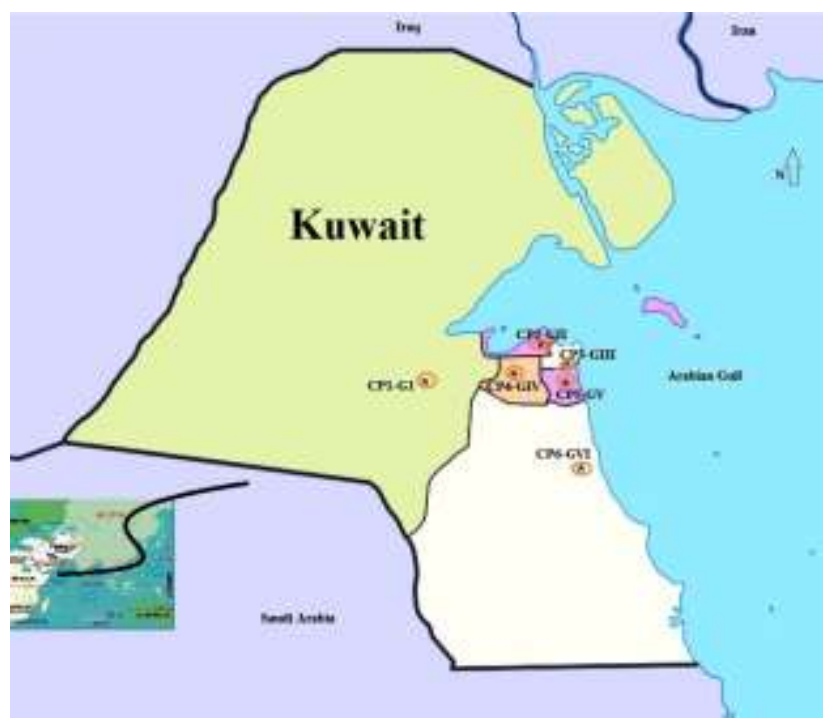

Fig. 1. Kuwait Map locating the car parks for radon concentrations

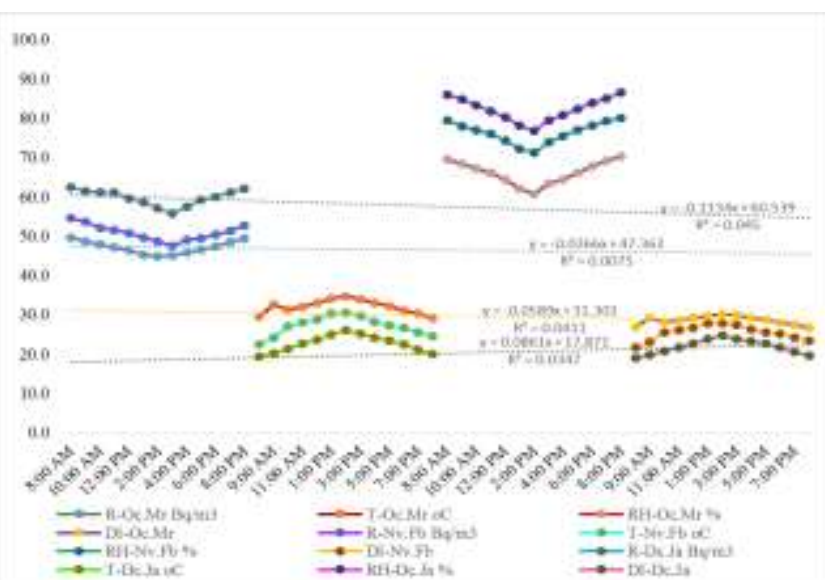

Fig. 2 Time-series radon concentrations, indoor variables and discomfort index during winter

R: radon, T: temperature, RH: relative humidity, DI: discomfort index, Oc: October, Mr: March, Nv: November Fb: February, Dc: December Ja: January

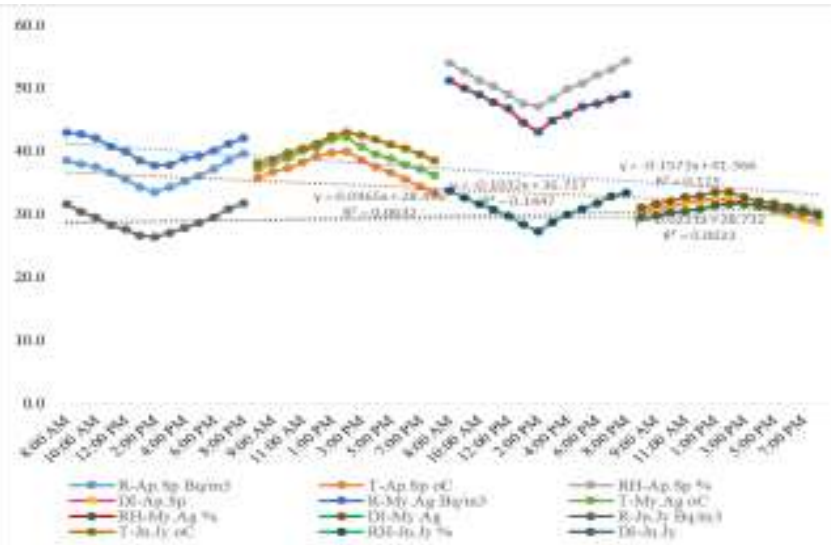

Fig.3 Time-series radon concentrations, indoor variables and discomfort index during summer

R: radon , T: temperature, RH: relative humidity, DI: discomfort index, Ap: April, Sp: September, My: May Ag: August, Jn: June, Jy: July 
Proc. of The Fifth Intl. Conf. On Advances in Applied Science and Environmental Engineering - ASEE 2016

Copyright (C) Institute of Research Engineers and Doctors, USA .All rights reserved

ISBN: 978-1-63248-086-6 doi: 10.15224/ 978-1-63248-086-6-02

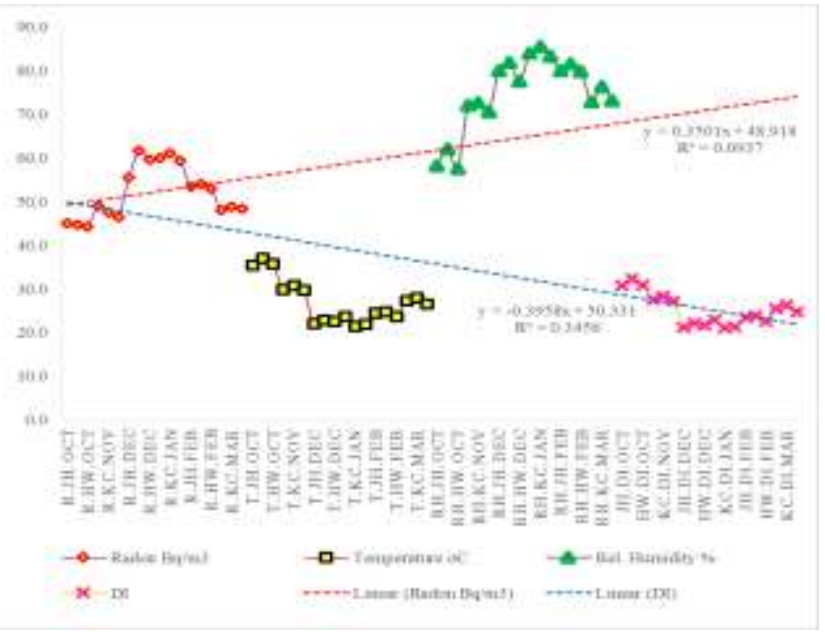

Fig.4a Site-wise radon concentrations, indoor variables and discomfort index in the Northern Kuwait area during winter R: radon, T: temperature, RH: relative humidity, DI: discomfort index, OCT: October, MAR:

March, NOV: November FEB: February, DEC: December JAN: January, JH: Jahra

(Governorate I), HW: Hawalli (Governorate III), KC: Kuwait City (Governorate II)

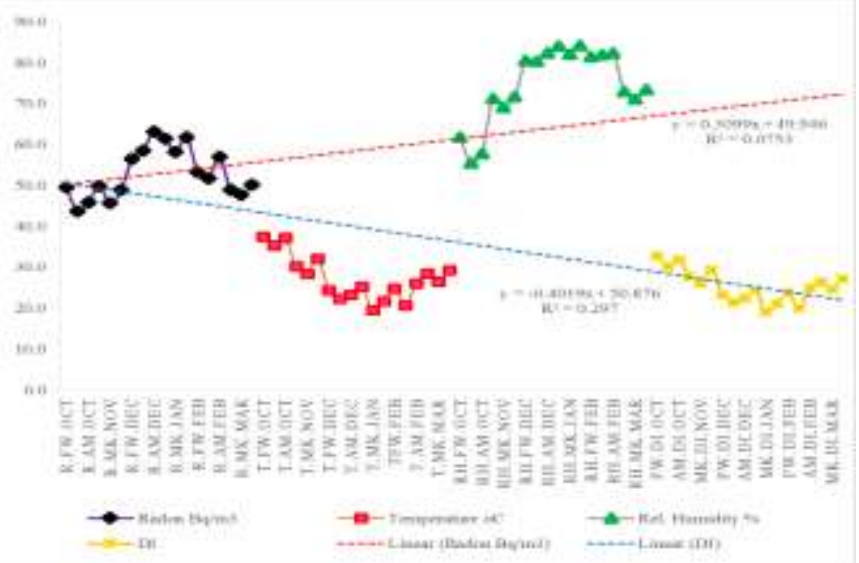

Fig. $4 \mathrm{~b}$ Site-wise radon concentrations, indoor variables and discomfort index in the Southern Kuwait area during winter $\mathrm{R}$ : radon, T: temperature, RH: relative humidity, DI: discomfort index, OCT: October, MAR: March, NOV: November FEB: February, DEC: December JAN: January, , FW: Farwaniya (Governorate IV), AM: Ahmedi (Governorate VI), MK: Mubarek al- Kabeer (Governorate V)

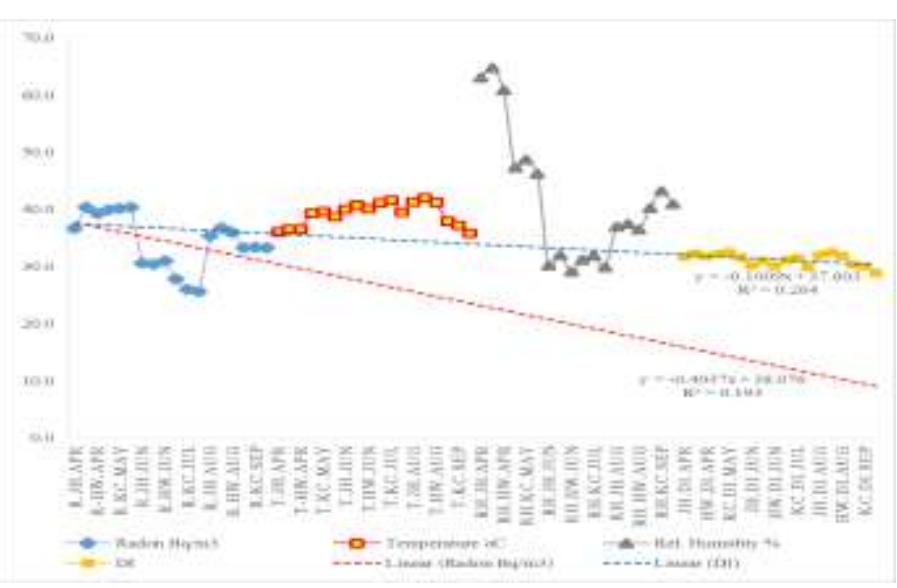

Fig.4c Site-wise radon concentrations, indoor variables and discomfort index in the Northern Kuwait area during summer
R: radon , T: temperature, RH: relative humidity, DI: discomfort index, Ap: April, Sp: September, My: May Ag: August, Jn: June, Jy: July, JH: Jahra (Governorate I), HW: Hawalli (Governorate III), KC: Kuwait City (Governorate II)

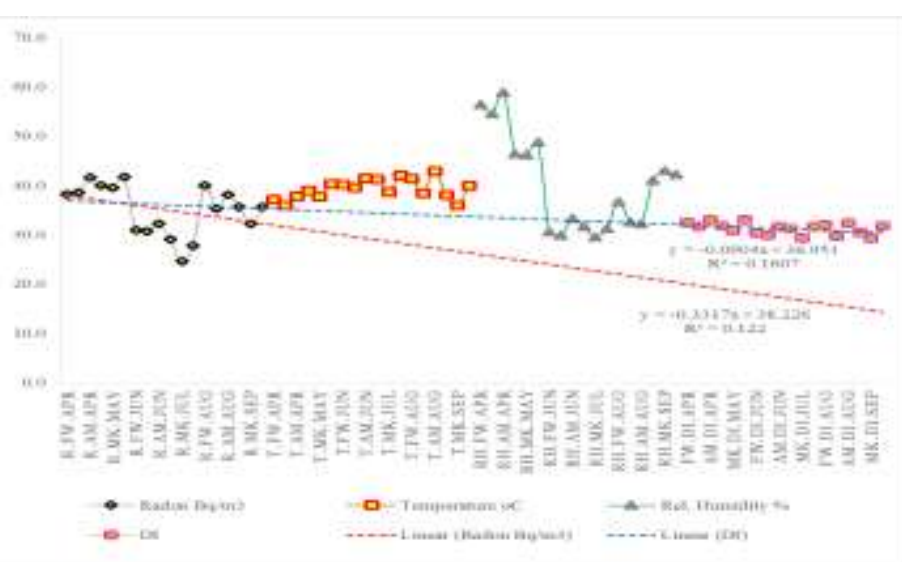

Fig.4d Site-wise radon concentrations, indoor variables and discomfort index in the Southern Kuwait area during summer

R: radon, T: temperature, RH: relative humidity, DI: discomfort index, Ap, Sp,My,Ag,Jn,Jy: April, September, May, August, June, July; FW: Farwaniya (G-IV), AM: Ahmedi (G-VI), MK: Mubarek al- Kabeer (G-V)

About Author (s):

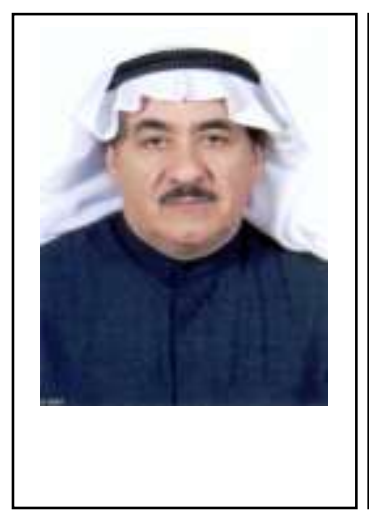

Professor AH Bu-Olayan, PhD (UK) Dept. of Chemistry Kuwait University, Ex-Chairman,

Specialization: Environmental Chemistry, Pollution in marine, land, arid, plants and health issues, 60 Publications; Awards: (Life Sciences) Scientific Achievement Prize, Kuwait Foundation for the Advancement of Science (KFAS), Kuwait

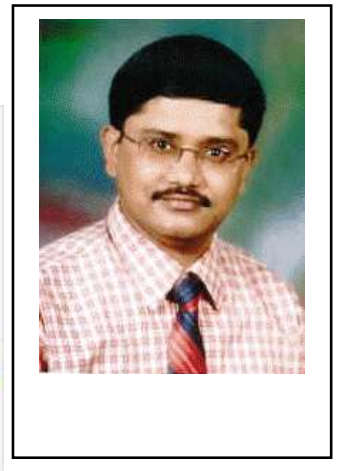

Dr. BV Thomas, FICCE, LFIBA (UK) Dept. of Chemistry, Kuwait University, Associate Researcher Specialization: Environmental Sciences, Pollution, aquaculture, toxicology, 48 Publications; Awards:

Marquis Who's Who in the World (US), Scientific Excellence, ABI (US), Outstanding intellectual (IBC, UK), Green Peace. 